\title{
Mycotoxins, pesticides and heavy metals content in the winter wheat grain at different cultivation technologies on leached Kuban chernozem
}

\author{
Irina Shabanova ${ }^{1,{ }^{*}}$, Nikolay Neshchadim ${ }^{1}$, Ksenia Gorpinchenko ${ }^{1}$, and Aleksandr Boyko ${ }^{2}$ \\ ${ }^{1}$ Kuban State Agrarian University named after I. T. Trubilin, 13, Kalinina str., Krasnodar 350044, \\ Russia \\ ${ }^{2}$ Federal research center all-Russian Institute of plant genetic resources named after N. I. Vavilov, 95, \\ Lenin Str., Adler, Sochi 354340, Russia
}

\begin{abstract}
The influence of fertilizers and plant protection products for the mycotoxins, pesticides and heavy metals accumulation in the grain of winter wheat variety Antonina grown at the experimental station of the Kuban University was investigated. In the resulted grain there were no traces of the fungicide "Фалькон", insecticide "Эйфория " and herbicide "Секатор турбо" used in the cultivation. The content of T-2 toxin is almost at the level of MPC $0.1 \mathrm{mg} / \mathrm{kg}$ in all variants of the experiment that indicates the fungal infection invading from the soil. The content of $\mathrm{Mn}, \mathrm{Cu}, \mathrm{Zn}, \mathrm{Pb}, \mathrm{Cd}, \mathrm{Co}, \mathrm{Ni}, \mathrm{Cr}$ in grain did not exceed MAC for adult nutrition.
\end{abstract}

\section{Introduction}

The rapid growth of the world's population, which will reach more than 9 billion by 2050 , and the reduction of arable land is a major challenge to achieving global food security. Intensification of agriculture is carried out by increasing the amount of fertilizers and variation of plant protection products, which may be accompanied by contamination of products with heavy metals, herbicides and pesticides [3, 10-11]. The decrease in grain quality is associated not only with the accumulation of heavy metals and pesticide residues in it, but also with the formation of mycotoxins. Schöneberg T. (2016) notes a tendency to increase the percentage of colonized kernels by fungi in grain from systems using more fertilizers and pesticides. From another point of view, a pesticide such as tricyclazole contributes to the destruction of the external protective layer of melanin pigment in the fungus cells [7]. The renovated values of content the toxins, pesticides and heavy metals in grain products were introduced in the EU in 2013. The technical regulations of the Customs Union "On safety of grain" were introduced in the Russian Federation in 2011. In the period from 2002 to 2013, about $16 \%$ of the oats samples in England contained more than 1000 ág $\mathrm{kg}^{-1}$ toxin HT2 + T2, exceeded MPC regulated in the Russian Federation [2].

\footnotetext{
*Corresponding author: Shabanova_I_V@mail.ru
} 
Problems arising with the quality of winter wheat grain, both in Russia and abroad, require a new approach to agrobiotechnologies $[4,6]$. Therefore, the purpose of our study was to develop a technology that allows obtaining quality winter wheat grain, suitable for the nutrition of adults and children.

\section{Materials and methods}

The research was conducted within the framework of long-term experience at the educational farm station "Kuban" in the territory of Krasnodar Region (Russia) in the period from 2015 to 2017. The cultivated crop is winter wheat (Triticum aestivum L.) cultivar Antonina, developed by scientists of Federal state budgetary scientific institution "NCG named after P. P. Lukyanenko" (Russia) and transferred to the state variety testing in 2013. The forecrop of winter wheat is sunflower. The crop rotation: corn for grain, winter wheat, sugar beet, winter wheat, spring barley with sowing of alfalfa, 2 and 3 years alfalfa; winter wheat, winter barley, sunflower, winter wheat. Soils are represented by leached Chernozem with the capacity of the humus layer $147 \mathrm{~cm}$, the reaction of the aqueous medium 6.5-8.2, humus content $2.5-2.9 \%$, mobile forms of nitrogen $-8 \%$, phosphorus$6.5-7.8 \%$, exchangeable potassium-50 t/ha [8-9]. The influence of three factors on the quality of winter wheat grain was studied: $\mathrm{A}-$ the amount of manure introduced in the beginning of rotation for corn on the grain, $\mathrm{t} / \mathrm{ha}$; B - mineral fertilizers and $\mathrm{C}$ - plant protection system (table 1).

Table 1. Scheme of experience.

\begin{tabular}{|c|c|c|c|}
\hline Variants & $\begin{array}{c}\text { Manure, } \mathrm{t} / \mathrm{ha} \\
\text { (factor } \mathrm{A} \text { ) }\end{array}$ & $\begin{array}{c}\text { Mineral fertilizers, } \\
\mathrm{kg} / \mathrm{ha} \text { (factor } \mathrm{B} \text { ) }\end{array}$ & $\begin{array}{c}\text { The system of plant } \\
\text { protection (factor) }\end{array}$ \\
\hline 000 & - & - & - \\
\hline 002 & - & - & Chemical \\
\hline 111 & 200 & $\mathrm{~N}_{70} \mathrm{P}_{45} \mathrm{~K}_{30}+\mathrm{N}_{30}$ & Biological \\
\hline 020 & - & $\mathrm{N}_{140} \mathrm{P}_{90} \mathrm{~K}_{60}+\mathrm{N}_{60}$ & - \\
\hline 200 & 400 & - & Chemical \\
\hline 022 & - & $\mathrm{N}_{140} \mathrm{P}_{90} \mathrm{~K}_{60}+\mathrm{N}_{60}$ & Chemical \\
\hline 202 & 400 & - & - \\
\hline 220 & 400 & $\mathrm{~N}_{140} \mathrm{P}_{90} \mathrm{~K}_{60}+\mathrm{N}_{60}$ & Chemical \\
\hline 222 & 400 & $\mathrm{~N}_{140} \mathrm{P}_{90} \mathrm{~K}_{60}+\mathrm{N}_{60}$ & Intensive \\
\hline 333 & 600 & $\mathrm{~N}_{280} \mathrm{P}_{180} \mathrm{~K}_{120}+\mathrm{N}_{120}$ & \\
\hline
\end{tabular}

Note. * Protection systems: biological - "Геостим" treatment at a rate of 1-2 liters per ha and "Бикол" (Bacillus thuringiensis var. thuringiensis, wetting powder, titer not less than 45 billion spores / g, BA-2000 EA/g) at a rate of 3-4 liters per ha ;

chemical - weeding with the herbicide "Секатор турбо" (amidosulfuron $100 \mathrm{~g} / \mathrm{l}$, iodosulfuronmethyl-sodium $25 \mathrm{~g} / 1$, mefenpyr-diethyl $25 \mathrm{~g} / \mathrm{l}$ ) at a dose of $0.075 \mathrm{~kg} / \mathrm{ha}$;

intensive - chemical + fungicide "Фалькон", (tebuconazole $167 \mathrm{~g} / 1+$ triadimenol $43 \mathrm{~g} / 1+$ spiroxamine $250 \mathrm{~g} / \mathrm{l}$ ) at a rate of 0.6 litres per hectare) + insecticide "Эйфория", (thiamethoxam and lambda-cyhalothrin) at a rate of 0.2 liters per hectare.

The grown grain was analyzed in the Federal state institution agrochemical service center "KRASNODARSKII" for the residual content of pesticides and mycotoxins by the chromatographic methods and the heavy metals of the first and second classes of danger on the atomic absorption spectrometer. 


\section{Result and discussion}

Analysis of winter wheat grain grown under intensive plant protection system showed that the content of insecticide residues, herbicides and fungicides does not exceed the MPC for adult nutrition table 2. Also, there are traces of organomercury pesticides and derivatives of 2,4-D acid in the grain, which were not used in wheat growing, due to their residual content in the soil. The content of T-2 toxin in the grain is almost at the level of MPC $0.1 \mathrm{mg} / \mathrm{kg}$, both under control and with intensive technology, which indicates the presence of fungal infection in the soil.

Table 2. Content of mycotoxins and pesticides in winter wheat grain varieties Antonina.

\begin{tabular}{|c|c|c|c|}
\hline \multirow{2}{*}{ Indicator } & \multicolumn{2}{|c|}{ Content, $\mathrm{mg} / \mathrm{kg}$} & \multirow[t]{2}{*}{$\mathrm{MPC}^{*}, \mathrm{mg} / \mathrm{kg}$} \\
\hline & 000 & 333 & \\
\hline \multicolumn{4}{|l|}{ Mycotoxins: } \\
\hline aflatoxin B1. & 0.003 & 0.003 & 0.005 \\
\hline deoxynivalenol & 0.23 & 0.27 & 0.70 \\
\hline $\mathrm{T}-2$ toxin. & 0.09 & 0.10 & 0.10 \\
\hline zearalenone & 0.15 & 0.18 & 1.00 \\
\hline ochratoxin A & 0.004 & 0.004 & 0.005 \\
\hline \multicolumn{4}{|l|}{ Pesticides : } \\
\hline DDT and its metabolites & 0.01 & 0.01 & 0.02 \\
\hline organomercury pesticides & 0.01 & 0.01 & absent \\
\hline 2,4-d acid, its salts, esters & 0.04 & 0.04 & absent \\
\hline spiroxamine & trace quantities & 0.011 & 0.2 \\
\hline propiconazole & trace quantities & 0.09 & 0.1 \\
\hline tebuconazole & trace quantities & 0.05 & 0.2 \\
\hline thiabendazole & trace quantities & 0.1 & 0.2 \\
\hline triadimenol & 0.005 & 0.015 & 0.2 \\
\hline \multicolumn{4}{|l|}{ Insecticides : } \\
\hline lambda-cyhalothrin & trace quantities & 0.05 & 0.01 \\
\hline thiamethoxam & trace quantities & 0.02 & 0.05 \\
\hline \multicolumn{4}{|l|}{ Herbicides: } \\
\hline amidosulfuron & trace quantities & следы & 0.1 \\
\hline $\begin{array}{l}\text { sodium iodosulfuron- } \\
\text { methyl }\end{array}$ & trace quantities & следы & 0.1 \\
\hline mefenpyr-diethy & trace quantities & следы & 0.5 \\
\hline
\end{tabular}

Notes. * Technical regulations of the Customs Union "On grain safety" TR CU 015/2011 dated 9.12.2011.

Heavy metals have dual nature, on the one hand - microelements $(\mathrm{Mn}, \mathrm{Cu}, \mathrm{Zn}, \mathrm{Co})$, on the other - especially dangerous substances of 1-3 class $(\mathrm{Zn}, \mathrm{Cu}, \mathrm{Pb}, \mathrm{Cd}, \mathrm{Cr}, \mathrm{Ni})$ [1, 5, 12]. The heavy metals content in winter wheat grain of Antonina variety does not exceed MPC for food of the adult population (table 3).

Table 3. Content of heavy metals in winter wheat grain varieties Antonina, $\mathrm{mg} / \mathrm{kg}$.

\begin{tabular}{|c|c|c|c|c|c|c|c|c|}
\hline Variants & $\mathrm{Mn}$ & $\mathrm{Co}$ & $\mathrm{Cr}$ & $\mathrm{Ni}$ & $\mathrm{Zn}$ & $\mathrm{Cu}$ & $\mathrm{Pb}$ & $\mathrm{Cd}$ \\
\hline 000 & 20.6 & 0.054 & 0.031 & 0.43 & 18.3 & 3.9 & 0.14 & 0.071 \\
\hline 111 & 21.2 & 0.048 & 0.016 & 0.53 & 17.6 & 3.8 & 0.15 & 0.058 \\
\hline 002 & 23.5 & 0.051 & 0.038 & 0.62 & 22.3 & 4.3 & 0.19 & 0.067 \\
\hline 020 & 23.6 & 0.045 & 0.016 & 0.59 & 16.8 & 2.8 & 0.12 & 0.061 \\
\hline 200 & 23.4 & 0.066 & 0.020 & 0.43 & 21.8 & 3.5 & 0.16 & 0.062 \\
\hline 022 & 22.6 & 0.063 & 0.014 & 0.50 & 17.1 & 2.9 & 0.15 & 0.066 \\
\hline 202 & 22.8 & 0.072 & 0.015 & 0.44 & 12.9 & 2.4 & 0.14 & 0.057 \\
\hline
\end{tabular}




\begin{tabular}{|c|c|c|c|c|c|c|c|c|}
\hline 220 & 24.0 & 0.070 & 0.016 & 0.38 & 14.2 & 2.9 & 0.14 & 0.071 \\
\hline 222 & 22.7 & 0.043 & 0.020 & 0.38 & 18.9 & 2.9 & 0.10 & 0.064 \\
\hline 333 & 22.4 & 0.046 & 0.017 & 0.28 & 19.2 & 2.5 & 0.17 & 0.078 \\
\hline LSD $_{05}$ & 1.9 & 0.01 & 0.01 & 0.05 & 0.5 & 0.2 & 0.05 & 0.01 \\
\hline MPC [3] & 140 & 1.0 & 0.5 & 1.0 & 50 & 10 & 0.50 & 0.1 \\
\hline
\end{tabular}

The high doses introduction of fertilizers and manure does not contribute to the accumulation of cobalt, chromium, nickel and copper in the grain; the content of manganese, zinc, lead and cadmium does not change significantly with different technologies.

The dependence of manganese, copper and zinc content in the grain is expressed by regression equations (Statistica 6.1), for lead, nickel and cadmium the regularity is not revealed:

$$
\begin{gathered}
\mathrm{C}(\mathrm{Zn})=45.9-0.5 \times \mathrm{A}-0.7 \times \mathrm{B}+0.8 \times \mathrm{C}, \\
\mathrm{C}(\mathrm{Cu})=47.7-0.3 \times \mathrm{A}-0.3 \times \mathrm{B}+0.2 \times \mathrm{C}, \\
\mathrm{C}(\mathrm{Mn})=33.4+0.23 \times \mathrm{B}-0.34 \times \mathrm{C}, \\
\mathrm{C}(\mathrm{Cr})=0.32-0.1 \times \mathrm{B}, \\
\mathrm{C}(\mathrm{Co})=0.72+0.1 \times \mathrm{B},
\end{gathered}
$$

where A - is manure,

B - fertilizers,

C - plant protection system.

The obtained coefficients are significant for manganese, copper and zinc in terms of the mineral fertilizers influence (20-35\%) and plant protection systems (about $35 \%$ ). For cadmium, lead and nickel there is no linear dependence, due to the influence of anthropogenic factors and the arrival of these metals in the soil with atmospheric rainfall.

The decrease in grain content in the variant with intensive technology compared to the control reaches - cobalt $20 \%$, chromium $45 \%$, nickel and copper $35 \%$, mainly due to the increase in yield and vegetative mass of plants.

\section{Conclusion}

The use of plant protection products, including herbicide application "Секатор турбо" (amidosulfuron, iodosulfuron-methyl-sodium, mefenpyr-diethyl), fungicide "Фалькон", (tebuconazole, triadimenol, spiroxamin), insecticide "Эйфория" (thiamethoxam and lambda-cyhalothrin) did not contribute to the accumulation of drugs residual quantities in the grain of winter wheat varieties Antonina.

T-2 toxin accumulation was observed at the level of MPC of $0.1 \mathrm{mg} / \mathrm{kg}$ in the control variant and with the use different doses of fertilizers and plant protection agents, that indicates the presence of fungal infection in the soil.

The content of $\mathrm{Mn}, \mathrm{Cu}, \mathrm{Zn}, \mathrm{Co}, \mathrm{Cr}, \mathrm{Ni}, \mathrm{Cd}, \mathrm{Pb}$ in grown grain did not exceed MPC in all variants of the experiment. There was a decrease in the content of cobalt, chromium, nickel and copper in the grain by $20-35 \%$ compared with the control, when applying high doses of fertilizers.

\section{References}

1. G. K. Devisetty, O. Abatashi, U. Salim and Z. Said Metal composition and essential nutrient analysis in various colours of lentils determination of essential nutrients levels 
and compositional analysis of metals in lentil, Research journal of pharmaceutical, biological and chemical sciences, 10 (1): 665-659 (2019)

2. S. G. Edwards Impact of agronomic and climatic factors on the mycotoxin content of harvested oats in the United Kingdom, Food Additives and Contaminants, 34(12): 2230-2241 (2018) https://doi.org/ 10.1080/19440049.2017.1372639

3. N.N. Neshchadim, A.A. Kvashin, L.V. Tsatsenko, I.V. Shabanova The effect of agricultural technologies on the dynamics of the content of $\mathrm{Mn}, \mathrm{Zn}, \mathrm{Cd}, \mathrm{Co}, \mathrm{Pb}$, and $\mathrm{Cu}$ in leached back soil of western ciscaucasia and maize grains, International Journal on Emerging Technologies, 11, 2, 978-984 (2020)

4. V. A. Isaichev, N. N. Andreev and K. A. Vinogradova The content of macroelements in barley grain after application of growth regulators and mineral fertilizer, Research journal of pharmaceutical, biological and chemical sciences, 9 (2), 1202-1206 (2018)

5. J. O. Jonsson and J. Eriksson The effect of fertilization for higher protein content on Cd level in wheat grain, Biogeochemistry of trace elements 7-th ICOBTE, 3, 242-243 (2003)

6. A. N. Kshnikatkina, P. G. Alenin and S. A. Kshnikatkin The yield and quality of hulless barley under foliar fertilization with microelement fertilizer in conditions of forest-steppe of the middle Volga region, Research journal of pharmaceutical, biological and chemical sciences. 9 (1): 90-94, (2018)

7. M. Kumar, R. Chand, K. Shah Mycotoxins and Pesticides: Toxicity and Applications in Food and Feed. Microbial Biotechnology, 207-252, (2018) https://doi.org/10.1007/978-981-10-7140-9 11

8. N. N. Neshchadim ,A. A. Kvashi, K.N. Gorpinchenko, Y.P. Fedulov International Journal of Engineering and Technology(UAE). 7(4.38 Special Issue 38), 685-689 (2018)

9. N. N. Neshchadim, L.V. Tsatsenko, S.S. Koshki, A.T. Kazartseva, Criteria for assessing the reproductive potential of traditional varieties of winter soft wheat and the possibility of their use in the selection process. Journal of Pharmaceutical Sciences and Research. 9(12), 2590-2595 (2017)

10. T. Schöneberg Fusarium and mycotoxin spectra in Swiss barley are affected by various cropping techniques, Food Additives and Contaminants, 33(10), 120 (2016)

11. A. Tyczewska, E. Woźniak, J. Gracz, Towards Food Security. Current State and Future $\begin{array}{llllll}\text { Prospects of Agrobiotechnology. 36, 12, 1219-1229 } & \text { (2018) }\end{array}$ https://doi.org/10.1016/j.tibtech.2018.07.008.

12. H. Wangstran, J. Eriksson and I. Oborn Cadmium concentration in winter wheat as affected by nitrogen fertilization. European Journal of Agronomy, 26, 209-214 (2007) 